\title{
Temporal Distribution Characteristic and Risk Analysis of Heavy Metals in Greenhouse Vegetable Soils
}

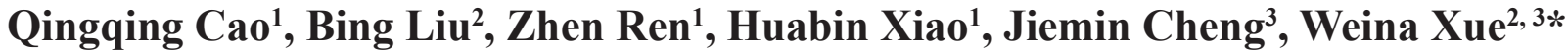 \\ ${ }^{1}$ School of Architecture and Urban Planning, Shandong Jianzhu University, Jinan, China \\ ${ }^{2}$ School of Municipal and Environmental Engineering, Shandong Jianzhu University, Jinan, China \\ ${ }^{3}$ College of Geography and the Environment, Shandong Normal University, Jinan, China
}

Received: 10 May 2019

Accepted: 25 July 2019

\begin{abstract}
The aim of this study was to explore the distribution characteristics, sources, ecological risks and health indexes of heavy metals in greenhouse vegetable soils (GVS) of vicennial cultivation. Concentrations of chromium $(\mathrm{Cr})$, nickel $(\mathrm{Ni})$, copper $(\mathrm{Cu})$, zinc $(\mathrm{Zn})$, cadmium $(\mathrm{Cd})$, and lead $(\mathrm{Pb})$ were detected, and principle component analysis and cluster analysis were conducted. The potential ecological risk index and health index of the metals were also calculated to evaluate their multi-effects. Concentrations of $\mathrm{Ni}, \mathrm{Cu}, \mathrm{Zn}, \mathrm{Cd}$, and $\mathrm{Pb}$ reached peaks in GVS duration of 6-10 or 11-15 years, representing the high metal accumulation. Additionally, concentrations of $\mathrm{Cr}$ were significantly higher during the first decade than the second decade of GVS duration, which may be related to its bio-accumulation and leaching. Metals in soil depths of 20-40 cm showed a trend of intensive accumulation, especially in the second decade of duration. Cluster analysis revealed that $\mathrm{Cr}$, $\mathrm{Ni}$, and $\mathrm{Zn}$ were mostly from similar anthropogenic activities, and significantly high $\mathrm{Cd}$ in the studied area indicated the excessive human input. Furthermore, risk index demonstrated that GVS duration of 6-10 years was in moderate ecological risk and GVS duration of the second decade had a high health index.
\end{abstract}

Keywords: farming duration, greenhouse vegetable soils, heavy metals, potential ecological risk, health index

\section{Introduction}

Heavy metal contamination in soils has been focused over centuries around the world [1]. Due to the emphasis on food safety, metal accumulation in farming

*e-mail: qingjeep@163.com soils is also widely studied, and particularly greenhouse vegetable soils (GVS) have higher metal concentrations than open field vegetable soils, which would bring about a greater threat to the ecological environment and human health by food chain and human exposure $[2,3]$. Two opinions were offered on metal accumulation and GVS duration. One view is that metal concentrations are increasing by perennial sowing, pesticide spraying 
and fertilization application, which dominated metal accumulation $[4,5]$. For example, concentrations of chromium $(\mathrm{Cr})$, lead $(\mathrm{Pb})$, zinc $(\mathrm{Zn})$, and copper $(\mathrm{Cu})$ were significantly correlated and increased with cultivating years in farming soils $[6,7]$. Another view is that metals have different distribution characteristics with the increase in cultivation ages. For example, no significant difference was observed in available contents of cadmium $(\mathrm{Cd})$ and $\mathrm{Zn}$ between four-year and 17-year-cultivation in GVS of eastern China [8]. In addition, concentrations of nickel $(\mathrm{Ni})$ and $\mathrm{Pb}$ also had no significant difference along with GVS duration [9].

Studies on temporal and vertical distribution of heavy metals in GVS were previously involved. Liu et al. (2011) argued that concentrations of $\mathrm{Cd}, \mathrm{Cu}$, and $\mathrm{Cr}$ had increasing trends during the process of vegetable growth in GVS, indicating metal accumulation with the cultivation years [10], while $\mathrm{Zn}$ and $\mathrm{Cr}$ had no significant difference and $\mathrm{Cd}$ significantly increased with the increase in GVS duration in southwestern China [11]. Previous studies showed that temporal distribution of every metal in GVS had considerable divergence, suggesting that the relevant research was limited and that further specialized studies were needed. Published data showed that metal concentration decreased with the increase in soil depths in agriculture [11, 12]. However, the vertical distribution pattern in the soil profile of GVS has been not particularly clear until now.

Metal accumulation in soils brought about a great deal of contamination to surroundings and threatened human health. Many models were discussed and calculated to evaluate the potential risk of heavy metals [13]. Based on the background values and toxicresponse factors of metals, the potential ecological risk index (RI) of heavy metals were explored to evaluate the contamination level to the environment $[14,15]$.
Metals in soils can also be absorbed into human organs by routes of incidental ingestion, dermal contact, and inhalation of soils, which further bring about health risks [16]. Thus, health index (HI) was also previously analyzed and modeled by combining the metal daily intake, exposure time, etc. [17].

The GVS of vicennial duration and three soil depths $(0-20,20-40$, and 40-60 cm) were collected and $\mathrm{Cr}, \mathrm{Ni}$, $\mathrm{Cu}, \mathrm{Zn}, \mathrm{Cd}$, and $\mathrm{Pb}$ were detected as the research issues in this study. The temporal and vertical distribution of heavy metals in different GVS durations were analyzed, and the sources of heavy metals in GVS were explored by cluster analysis and principle correlation analysis. Furthermore, the potential ecological risk and health risk of heavy metals in the GVS were assessed by calculating the RI and HI.

\section{Material and Methods}

\section{Study Areas and Sample Collection}

Samples were collected from GVS in Lanling, Linyi of Shandong Province, China, in December 2017. Three sites were collected from greenhouses during the cultivation ages of $1,3,5,8,9,10,12,13,15,18$, and 20 years, respectively. As a reference, three sites were also selected and collected in open-field vegetable soils around the greenhouse area. For each sampling site, soils were collected at three depths $(0-20,20-$ 40 , and $40-60 \mathrm{~cm})$ and by five-point sampling method in $1 \mathrm{~m}^{2}$ [18]. Thus, 108 soil samples were collected in this study. Due to the vegetable types in GVS varying from season to season per year, metal bio-accumulation was considered as uniform in this study. The sampling positions are described in Fig. 1.
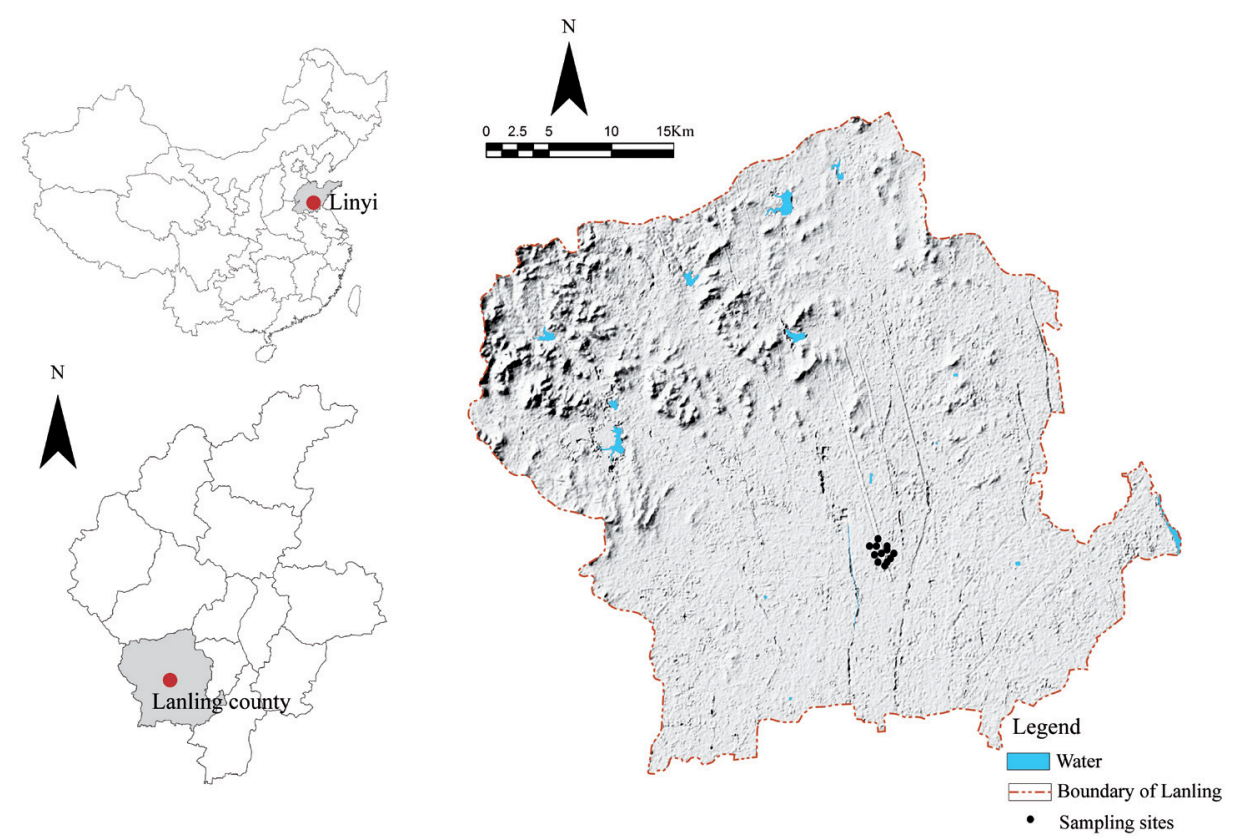

Fig. 1. Studied areas and sampling sites. 


\section{Sample Treatments}

Dried at $20^{\circ} \mathrm{C}$, soil samples were ground and then sifted through a $0.8-\mathrm{mm}$ nylon sieve for analysis of soil $\mathrm{pH}$ and cation exchange capacity (CEC). Then concentrations of heavy metals were determined after sifted through a $0.149-\mathrm{mm}$ nylon sieve. In detail, $0.2000 \mathrm{~g}$ of each sample was weighed and digested in the polytetrafluoroethylene crucibles with a mixture of $10 \mathrm{ml} \mathrm{HNO}_{3}, 5 \mathrm{ml} \mathrm{HF}$, and $2 \mathrm{ml} \mathrm{HClO}_{4}$. Covering up for 12 hours at $130^{\circ} \mathrm{C}$, the temperature was then increased to $180^{\circ} \mathrm{C}$, and the lids were taken off until residues were less than $1 \mathrm{ml}$. The final residues were dissolved in $1 \mathrm{ml}$ $\mathrm{HNO}_{3}(50 \%)$ and diluted to a volumetric flask of $25 \mathrm{ml}$ [19]. All glassware used were cleaned by soaking in $10 \%$ dilute nitric acid for at least $24 \mathrm{~h}$ and rinsed abundantly in deionized water before use during the digestion of heavy metals.

The concentrations of $\mathrm{Cr}, \mathrm{Cu}, \mathrm{Ni}$, and $\mathrm{Zn}$ were measured by inductively coupled plasma atomic emission spectrometry (ICP-AES; IRIS Advantage OPTIMA 7000DV, THERMO, America) with a detection wavelength of $170-850 \mathrm{~nm}$. Soil samples were analyzed for $\mathrm{Cd}$ and $\mathrm{Pb}$ by using graphite furnace atomic absorption spectrometry (GFAAS; PE800, American PE Company, America) with a detection limit of 10-13 g $\cdot \mathrm{mL}^{-1}$. Jiangsu Province and Shandong Province have the largest vegetable production and greenhouse vegetable bases in China, which mostly centered on the cities of Shouguang, Nanjing, Linyi, and Dongtai [20, 21]. Thus, the relevant literatures were retrieved and metal concentrations in GVS were compared in this study.

For the determination of $\mathrm{pH}, 10 \mathrm{~g}$ of soils and $25 \mathrm{~g}$ of distilled water were thoroughly mixed, stirred, and determined by using a $\mathrm{pH}$ meter (Rex PHS-3E; Shanghai INESE Scientific Instrument Co., Ltd). Soil samples $(2.00 \mathrm{~g})$ were mixed with $\mathrm{CH}_{3} \mathrm{COONH}_{4}$ and then $\mathrm{C}_{2} \mathrm{H}_{5} \mathrm{OH}$ solution, then they were distilled and titrated by solution of $\mathrm{HCl}$, and concentrations of CEC were calculated by recording the volume of hydrochloric acid in titration. The detailed methodology to determine CEC was previously reported by Shiri et al. [22].

\section{Potential Ecological Risk Index (RI)}

Risk index (RI) was introduced to assess the potential ecological risk of contamination in soils and sediments, and its calculation was listed as follows $[15$, 23]:

$$
\begin{gathered}
R I=\sum_{i=1}^{n} E_{r}^{i}=\sum_{i=1}^{n} T_{r}^{i} * C_{f}^{i} \\
C_{f}^{i}=\frac{c_{n}^{i}}{c_{0}^{i}}
\end{gathered}
$$

...where $c_{n}{ }^{i}$ is the concentration of any metal in samples, and $c_{0}{ }^{i}$ is the corresponding background value of metal, which are 66.6, 29.6, 22.1, 71.1, 0.103, and $21.9 \mathrm{mg} \cdot \mathrm{kg}^{-1}$ for $\mathrm{Cr}, \mathrm{Ni}, \mathrm{Cu}, \mathrm{Zn}, \mathrm{Cd}$, and $\mathrm{Pb}$, respectively referring to the background value of yellow fluvo-aquic soils in Shandong Province in this study [24]. $\mathrm{E}_{\mathrm{r}}^{\mathrm{i}}$ is the monomial potential ecological risk factor, and $\mathrm{T}^{\mathrm{i}}{ }_{\mathrm{r}}$ is the toxicresponse factor, which for $\mathrm{Cr}, \mathrm{Ni}, \mathrm{Cu}, \mathrm{Zn}, \mathrm{Cd}$, and $\mathrm{Pb}$ are $2,5,5,1,30$, and 5 , respectively [25]. The risk rank and evaluation classification are listed in Table 1 [23].

\section{Health Index (HI)}

Humans are vulnerable to heavy metals during agricultural activities in greenhouse vegetable, and incidental ingestion is a major route of exposure to metals for human beings [16]. A model of the human health index (HI) is determined by calculating the chemical daily intake (CDI) through incidental ingestion, summing hazard quotient (HQ) for non-carcinogenic chemicals, and evaluating carcinogenic risk (CR) for carcinogenic chemicals [26, 27]. Metal of $\mathrm{Cd}$ has strong carcinogenic capability as the classification for carcinogenicity of heavy metals [26], thus carcinogenic risk for $\mathrm{Cd}$ is conducted in this study. The health risk of children is not calculated in this study as children rarely appear in greenhouses.

The CDI of metals through incidental ingestion is calculated as the following formula:

$$
C D I_{\text {ingestion }}=C S \times I R \times \frac{E F \times E D}{B W \times A T} \times 10^{-6}
$$

In this study, $\mathrm{CDI}_{\text {ingestion }}$ is the daily take of metals $\left(\mathrm{mg} \cdot \mathrm{kg}^{-1}\right.$ day $\left.^{-1}\right)$ through incidental ingestion; CS is the concentrations of metals in soils $\left(\mathrm{mg} \cdot \mathrm{kg}^{-1}\right)$; and IR is the ingestion rate: $100 \mathrm{mg} \cdot \mathrm{day}^{-1}$ for adults [28]. EF is the exposure frequency, understood as $365 \mathrm{~d} \cdot \mathrm{yr}^{-1}$; ED is the

Table 1. Risk rank and evaluation classificationsof $\mathrm{E}_{\mathrm{i}}$ and RI [23].

\begin{tabular}{|c|c|c|c|c|c|}
\hline \multicolumn{2}{|c|}{ The risk rank of $C_{\mathrm{f}}^{i}$} & \multicolumn{2}{c|}{ Risk rank of $\mathrm{E}_{\mathrm{i}}$} & \multicolumn{2}{c|}{ Risk rank of RI } \\
\hline$C_{\mathrm{f}}^{i}<1$ & Low contamination & $\mathrm{E}_{\mathrm{i}}<40$ & Low risk & $\mathrm{RI}<150$ & Low risk \\
\hline $1 \leq C_{\mathrm{f}}^{i}<3$ & Moderate contamination & $40 \leq \mathrm{E}_{\mathrm{i}}<80$ & Moderate risk & $150 \leq \mathrm{RI}<300$ & Moderate risk \\
\hline $3 \leq C_{\mathrm{f}}^{i}<6$ & Considerable contamination & $80 \leq \mathrm{E}_{\mathrm{i}}<160$ & Considerable risk & $300 \leq \mathrm{RI}<600$ & Considerable risk \\
\hline$C_{\mathrm{f}}^{i} \geq 6$ & Very high contamination & $320>\mathrm{E}_{\mathrm{i}}>160$ & Great risk & $\mathrm{RI}>600$ & Very great risk \\
\hline
\end{tabular}


Table 2. Concentrations of heavy metals in soils of typical greenhouse bases of China $\left(\mathrm{mg} \cdot \mathrm{kg}^{-1}\right)$.

\begin{tabular}{|c|c|c|c|c|c|c|c|c|}
\hline Study area & $\mathrm{N}^{*}$ & $\mathrm{Cr}$ & $\mathrm{Ni}$ & $\mathrm{Cu}$ & $\mathrm{Zn}$ & $\mathrm{Cd}$ & $\mathrm{Pb}$ & $\mathrm{References}$ \\
\hline Linyi, Shandong Province & 108 & 88.23 & 39.00 & 37.62 & 111.35 & 0.52 & 29.87 & $\mathrm{This} \mathrm{study}$ \\
\hline Shouguang, Shandong Province & 59 & 67.13 & 28.93 & 27.86 & 115.79 & 0.196 & 20.06 & {$[21]$} \\
\hline Shouguang, Shandong Province & 65 & - & - & 32.9 & 106 & 0.44 & 20.7 & {$[8]$} \\
\hline Shouguang, Shandong Province & 69 & 41.34 & 28.02 & 28.43 & 90.76 & 0.21 & 15.32 & {$[29]$} \\
\hline Dongtai, Jiangsu Province & 108 & 49.33 & 21.3 & 14.87 & 56.63 & 0.16 & 17.58 & {$[19]$} \\
\hline Nanjing, Jiangsu Province & 112 & - & - & 52.17 & 117.4 & 0.15 & 53 & {$[27]$} \\
\hline Nanjing, Jiangsu Province & 85 & - & - & 36.4 & 95.56 & 0.23 & 32.19 & {$[20]$} \\
\hline Nanjing, Jiangsu Province & 320 & - & - & 37.68 & 98.01 & 0.21 & 37.3 & {$[8]$} \\
\hline
\end{tabular}

*: the numbers of samples.

exposure duration (ED) and the body weight (BW) are 30 years and $70 \mathrm{~kg}$ for adults [26]. AT is averaging time (for non-carcinogens, $\mathrm{TA}=\mathrm{ED} \times 365$; for carcinogens, $\mathrm{TA}=70 \times 365$ ).

$\mathrm{HQ}$ for non-carcinogenic metals and the $\mathrm{CR}$ for carcinogenic $\mathrm{Cd}$ were calculated as the following formulas:

$$
\begin{gathered}
H I=\sum_{\mathrm{i}=1}^{6} H Q=\sum_{i=1}^{6} \frac{C D I}{R f D} \\
C R=C D I \times S F
\end{gathered}
$$

$\mathrm{HI}$ is the sum of HQ for the six metals in this study. As the oral reference dose (RfD), RfD of $\mathrm{Cr}, \mathrm{Ni}$, $\mathrm{Cu}, \mathrm{Zn}, \mathrm{Cd}$, and $\mathrm{Pb}$ are 0.003, 0.02, 0.037, 0.3, 0.001 and $0.0035 \mathrm{mg} \cdot \mathrm{kg}^{-1} \mathrm{~d}^{-1}$ respectively for non-carcinogenic metals $\left(\mathrm{mg} \cdot \mathrm{kg}^{-1} \mathrm{~d}^{-1}\right)$. SF is the slope factor of carcinogenic chemicals and $\mathrm{SF}$ of $\mathrm{Cd}$ is $0.38 \mathrm{~kg} \cdot \mathrm{d} \cdot \mathrm{mg}^{-1}$ [26]. The acceptable $\mathrm{CR}$ is between $1 \times 10^{-6}$ and $1 \times 10^{-4}$. The risk of non-carcinogenic metals is low when the $\mathrm{HQ}<1$, and this risk exists when $\mathrm{HQ}>1$.

\section{Results}

\section{Temporal and Vertical Distribution Characteristics of Heavy Metals}

The average concentrations of the studied metals were $88.23 \mathrm{mg} \cdot \mathrm{kg}^{-1}$ for $\mathrm{Cr}, 39.00 \mathrm{mg} \cdot \mathrm{kg}^{-1}$ for $\mathrm{Ni}$, $37.62 \mathrm{mg} \cdot \mathrm{kg}^{-1}$ for $\mathrm{Cu}, 111.35 \mathrm{mg} \cdot \mathrm{kg}^{-1}$ for $\mathrm{Zn}, 0.52 \mathrm{mg} \cdot \mathrm{kg}^{-1}$ for $\mathrm{Cd}$ and $29.87 \mathrm{mg} \cdot \mathrm{kg}^{-1}$ for $\mathrm{Pb}$, respectively, which exceeded the background values (Fig. 2). Specifically, Cd was significantly higher in GVS $\left(0.55 \mathrm{mg} \cdot \mathrm{kg}^{-1}\right)$ than in open field $\left(0.19 \mathrm{mg} \cdot \mathrm{kg}^{-1}\right)$, indicating the high accumulation of Cd in GVS.

Comparison analysis of heavy metals in GVS according to literature retrieval were listed in Table 2. GVS of Lanling, Linyi in this study had the highest $\mathrm{Cr}, \mathrm{Ni}$, and $\mathrm{Cd}$, whereas concentrations of $\mathrm{Cu}$ and
$\mathrm{Pb}$ in Nanjing were relatively high, reflecting that accumulation levels of heavy metals were greatly distinguished from different areas.

The metals had different distribution patterns among cultivation ages of every five-year period in this study. The $\mathrm{Cr}$ and Ni showed a decreased trend with significantly higher concentrations in the first decade of duration than the second decade duration of GVS. The result indicated an export trend of $\mathrm{Cr}$ and $\mathrm{Ni}$ with the increase in cultivation ages, dominance of which can be plant bio-accumulation (Table 3). Metal of $\mathrm{Cu}$ reached a peak in GVS duration of 6-10 years, revealing that the accumulation of $\mathrm{Cu}$ was not consistent with the increase in GVS duration (Fig. 2). Concentration of $\mathrm{Cd}$ was significantly lower in GVS duration of $1-5$ years and open field, while accumulating the most in duration of 6-10 years $\left(0.70 \mathrm{mg} \cdot \mathrm{kg}^{-1} ; \mathrm{P}<0.05\right)$. Metals of $\mathrm{Zn}$ and $\mathrm{Pb}$ showed no significant distribution difference among the GVS duration. The highest standard deviation of $\mathrm{Zn}$ and $\mathrm{Pb}$ in duration of 1-5 years suggested that this duration period of GVS was vulnerable to $\mathrm{Zn}$ and $\mathrm{Pb}$ contamination.

Characteristics of metal leaching in the soil profile can be indicated by evaluating the differences of metal concentrations among the three soil depths $(0-20 \mathrm{~cm}$, $20-40 \mathrm{~cm}$, and $40-60 \mathrm{~cm}$ ) in this study. The subtracted concentrations of $\mathrm{Cr}, \mathrm{Ni}$, and $\mathrm{Cu}$ from soil depth of $20-40 \mathrm{~cm}$ to that of $0-20 \mathrm{~cm}$ or $40-60 \mathrm{~cm}$ were mostly positive values (Fig. 3) - especially in the second decade duration of GVS. The finding revealed the intensive metal accumulation in soil depth of 20-40 cm and may be caused by agriculture activities, metal accumulation in roots, and root decomposition. The $\mathrm{pH}$ was higher in open field and GVS duration of 1-5 years than in other cultivation ages, representing soil acidification with the increase in GVS duration. The CEC was the highest in open field (45.8) and lowest in GVS of the second decade duration (23.6), exhibiting a decreasing absorption on cation with the increase in GVS duration.

Previous studies indicated that coefficient of variation (CV) of heavy metals would exceed $20 \%$ when suffering from anthropogenic activities [4]. The $\mathrm{CV}$ of $\mathrm{Cd}$ and 


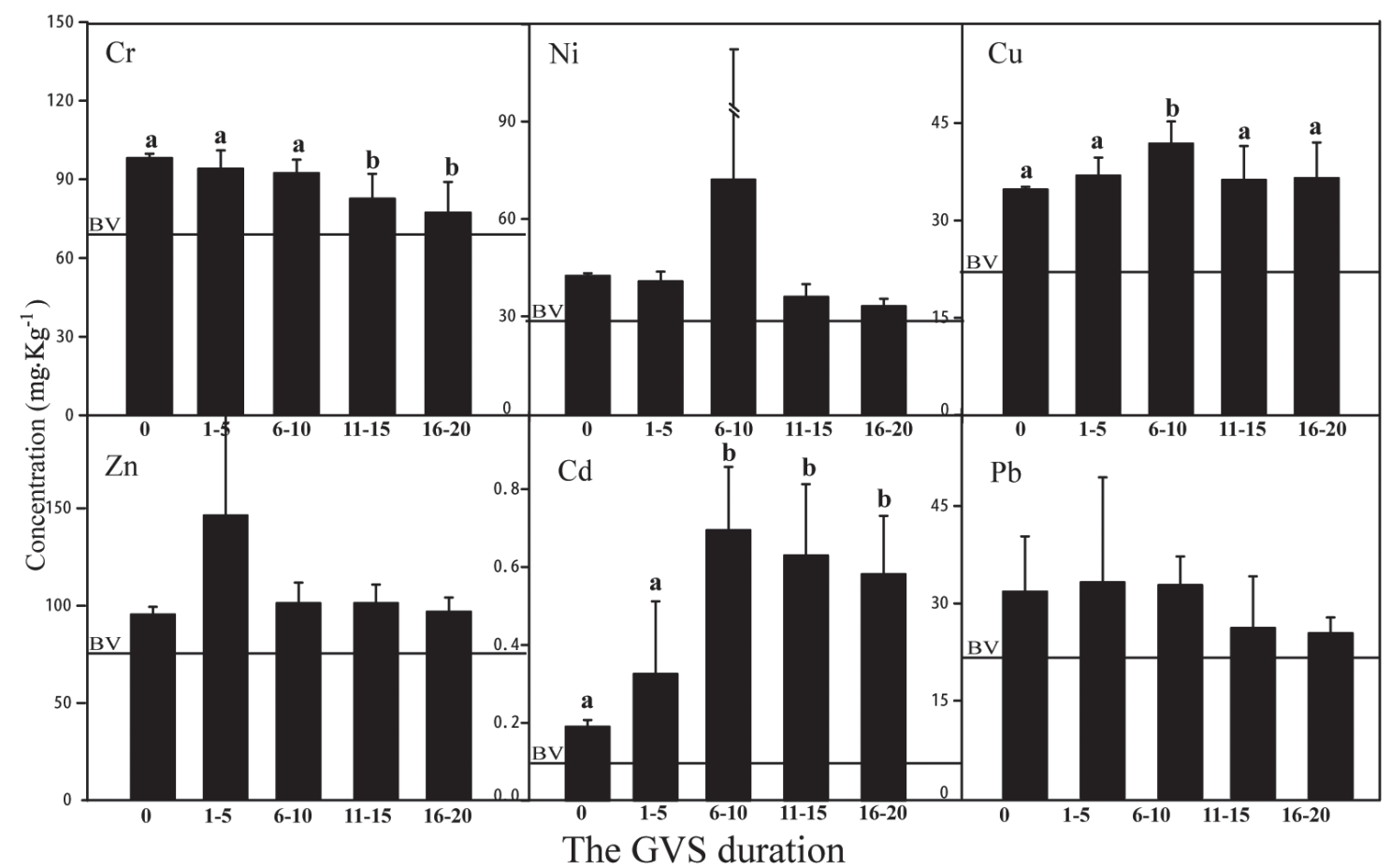

Fig. 2. Distribution patterns of heavy metals in GVS duration of 20 years; BV: background values of the metals; bars sharing the same lowercase letter ( $a$ or $b$ ) are not significant at $\alpha=0.05$ (Duncan test).

$\mathrm{Pb}$ were $40.3 \%$ and $34.1 \%$ in this study, indicating the human effect (Table 3). The significantly higher $\mathrm{CV}$ of $\mathrm{Zn}(61.3 \%), \mathrm{Cd}(57.3 \%)$, and $\mathrm{Pb}(48.6 \%)$ in GVS duration of 1-5 years revealed the prominent anthropogenic input during cultivation. Metal concentrations and CV had no remarkable difference or significant trend among the soil profile in this study, a finding that may be related to soil plowing and turning up and further reflects that metal accumulation in subsurface soils can also be directly affected by human activities. With notably higher CV of the metals in GVS than those in open field, the CV decreased with the order: $\mathrm{Zn}(44.4 \%)>\mathrm{Cd}(40.3 \%)>\mathrm{Pb}$ $(34.1 \%)>\mathrm{Ni}(13.4 \%)>\mathrm{Cu}(12.4 \%)>\mathrm{Cr}(12.0 \%)$.
The principal component analysis (PCA) and factor analysis were conducted and three primary factors were extracted by factor analysis on the metals $\mathrm{pH}$ and CEC (Fig. 4). Results showed that factor 1 was dominated by $\mathrm{Cr}, \mathrm{Ni}, \mathrm{Cu}, \mathrm{Pb}$, and $\mathrm{CEC}$, and explained $37.8 \%$ of the total variances. With the contribution of $11.6 \%$ and $13.4 \%$ to the variances, factor 2 and factor 3 were mainly dominated by $\mathrm{Cd}$ and $\mathrm{Zn}$, respectively. The PCA showed that most samples were concentrated near the coordinates, and principal component 1 and principal component 2 explained $94.1 \%$ of the total variances. Cluster analysis on the six metals according to correlation analysis showed that $\mathrm{Cu}, \mathrm{Ni}$, and $\mathrm{Cr}$ were

Table 3. Concentrations of heavy metals in GVS duration $\left(\mathrm{mg} \cdot \mathrm{kg}^{-1}\right)$.

\begin{tabular}{|c|c|c|c|c|c|c|c|c|}
\hline \multicolumn{2}{|c|}{ GVS duration (year) } & $\mathrm{Cr} * *$ & $\mathrm{Ni}$ & $\mathrm{Cu}$ & $\mathrm{Zn}$ & $\mathrm{Cd}$ & $\mathrm{Pb}^{*}$ & $\mathrm{CEC} * *$ \\
\hline \multirow{4}{*}{ Open field } & Mean (SD) & $98.1(1.7)$ & $42.5(0.8)$ & $34.8(0.4)$ & $95.4(4)$ & $0.19(0.02)$ & $31.8(8.5)$ & $45.8(3.2)$ \\
\cline { 2 - 9 } & Range & $96.8-100$ & $41.9-43.4$ & $34.4-35.2$ & $90.9-97.7$ & $0.17-0.2$ & $23.5-40.5$ & $43.2-49.4$ \\
\cline { 2 - 9 } & $\mathrm{CV}(\%)$ & 1.7 & 1.9 & 1.2 & 4.2 & 9.1 & 26.8 & 7 \\
\hline \multirow{4}{*}{$1-10$} & Mean (SD) & $93.3(6)$ & $42.3(3.6)$ & $39.2(3.9)$ & $123.8(66.2)$ & $0.5(0.26)$ & $33(11.8)$ & $31.3(4.4)$ \\
\cline { 2 - 9 } & Range & $81.8-106.3$ & $36.1-49.1$ & $33.9-47.8$ & $78.5-300.9$ & $0.2-0.9$ & $18.3-73.9$ & $23.2-38.8$ \\
\cline { 2 - 9 } & $\mathrm{CV}(\%)$ & 6.5 & 8.6 & 10 & 53.5 & 51.1 & 35.7 & 14.2 \\
\hline \multirow{3}{*}{$11-20$} & Mean (SD) & $80.5(10.4)$ & $34.8(3.5)$ & $36.4(5.1)$ & $99.6(8.7)$ & $0.61(0.17)$ & $25.9(6.2)$ & $23.8(2.2)$ \\
\cline { 2 - 9 } & Range & $58.5-103.9$ & $30-43.3$ & $28.2-44.5$ & $87.7-111.3$ & $0.35-0.9$ & $12.5-39.1$ & $20.2-27.7$ \\
\cline { 2 - 9 } & CV (\%) & 12.9 & 10.2 & 14.1 & 8.7 & 27.3 & 23.9 & 9.3 \\
\hline
\end{tabular}

*: $\mathrm{P}<0.05$ in concentrations of metals; **: $\mathrm{P}<0.01$ in concentrations of metals. SD: standard deviation; $\mathrm{CV}$ : coefficient of variation. 


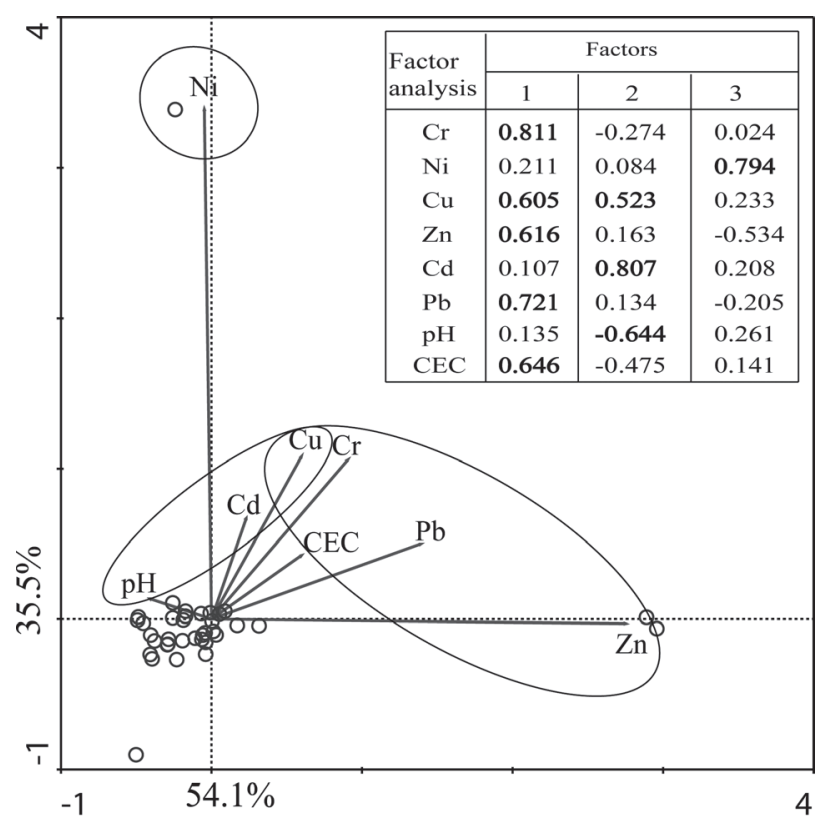

Fig. 3. Cluster analysis and comparison analysis of heavy metals $\left(\mathrm{mg} \cdot \mathrm{kg}^{-1}\right.$; metals 1, 2 and 3 refer to metal concentrations in soil depth of 0-20 cm, 20-40 cm, and 40-60 cm).

significantly and positively clustered, and then gathered the cluster of $\mathrm{Pb}$ and $\mathrm{Zn}$ (Fig. 3).

\section{Potential Ecological Risk Index (RI) and Human Health Risk Index (HI)}

The $E_{i}$ and $R$ revealed the damaging degree of potential pollution to the terrestrial soils or sediments (Table 4). $\mathrm{E}_{\mathrm{i}}$ of the six metals suggested that contamination by $\mathrm{Cr}, \mathrm{Ni}, \mathrm{Cu}, \mathrm{Zn}$, and $\mathrm{Pb}$ in two decades of GVS duration were at low risk. But for the $\mathrm{E}_{\mathrm{i}}$ of $\mathrm{Cd}$, it showed low ecological risk in open field, moderate risk in GVS duration of 1-5 years, and considerable risk in GVS of other cultivation duration (Table 4), which indicated the potential harm to ecological environment and further to human health. $\mathrm{R}$ of the six metals revealed that GVS duration of 1-5 years was in moderate risk, whereas other GVS durations were in low risk. Moreover, R in GVS duration of the first decade was

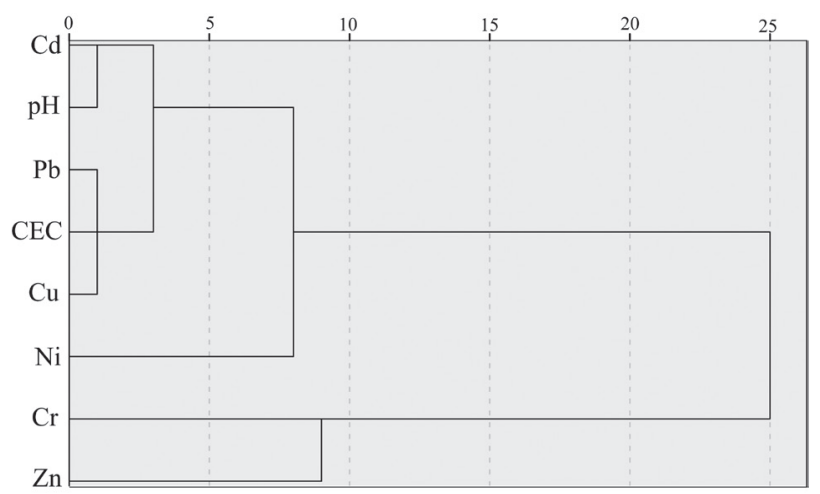

Fig. 4. Factor analysis and principal component analysis (PCA) on metals, $\mathrm{pH}$, and CEC of GVS (CEC: cation exchange capacity).

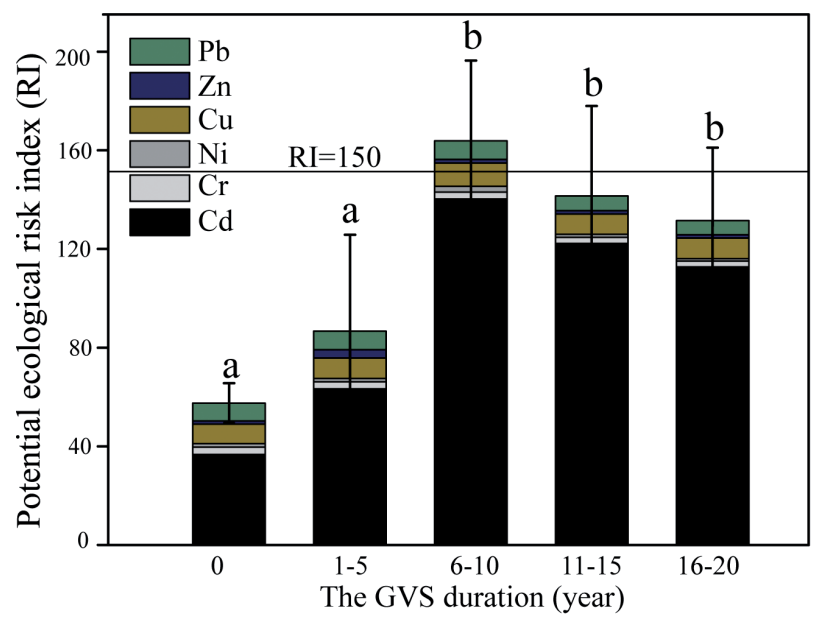

Fig. 5. Potential ecological risk index (R) of metals at different GVS durations; bars sharing the same lowercase letter (a or b) are not significant at $\alpha=0.05$ (Duncan test).

significantly lower than that in GVS duration of the second decade (Fig. 5). The non-significant difference of RI among the soil depths indicated that potential ecological risk polluted by the metals cannot be avoided in deep soils.

Table 4. Potential ecological risk index (R) of heavy metals at different GVS durations.

\begin{tabular}{|c|c|c|c|c|c|c|c|}
\hline GVS duration (year) & $\mathrm{E}_{\mathrm{i}}(\mathrm{Cr})$ & $\mathrm{E}_{\mathrm{i}}(\mathrm{Ni})$ & $\mathrm{E}_{\mathrm{i}}(\mathrm{Cu})$ & $\mathrm{E}_{\mathrm{i}}(\mathrm{Zn})$ & $\mathrm{E}_{\mathrm{i}}(\mathrm{Cd})$ & $\mathrm{E}_{\mathrm{i}}(\mathrm{Pb})$ & $\mathrm{RI}$ \\
\hline Open field & $2.95 \mathrm{a}$ & 1.44 & $7.86 \mathrm{a}$ & 1.36 & $36.67 \mathrm{a}$ & 7.26 & 57.54 \\
\hline $1-5$ & $2.83 \mathrm{a}$ & 1.38 & $8.35 \mathrm{ab}$ & 3.31 & $63.29 \mathrm{a}$ & 7.59 & 86.74 \\
\hline $6-10$ & $2.79 \mathrm{a}$ & 2.33 & $9.42 \mathrm{~b}$ & 1.45 & $140.31 \mathrm{~b}$ & 7.60 & 163.89 \\
\hline $11-15$ & $2.48 \mathrm{~b}$ & 1.22 & $8.20 \mathrm{a}$ & 1.39 & $122.26 \mathrm{~b}$ & 5.98 & 141.53 \\
\hline $16-20$ & $2.32 \mathrm{~b}$ & 1.12 & $8.26 \mathrm{a}$ & 1.29 & $112.73 \mathrm{~b}$ & 5.80 & 131.52 \\
\hline Mean values & 2.66 & 1.54 & 8.53 & 1.87 & 103.31 & 6.86 & 124.76 \\
\hline
\end{tabular}

$\mathrm{E}_{\mathrm{i}}(\mathrm{Cr})$ : The potential ecological risk index of monomial metal. The different letters ( $\mathrm{a}$ or $\mathrm{b}$ ) in each column indicate the significant differences at $\alpha=0.05$ (Duncan test). 


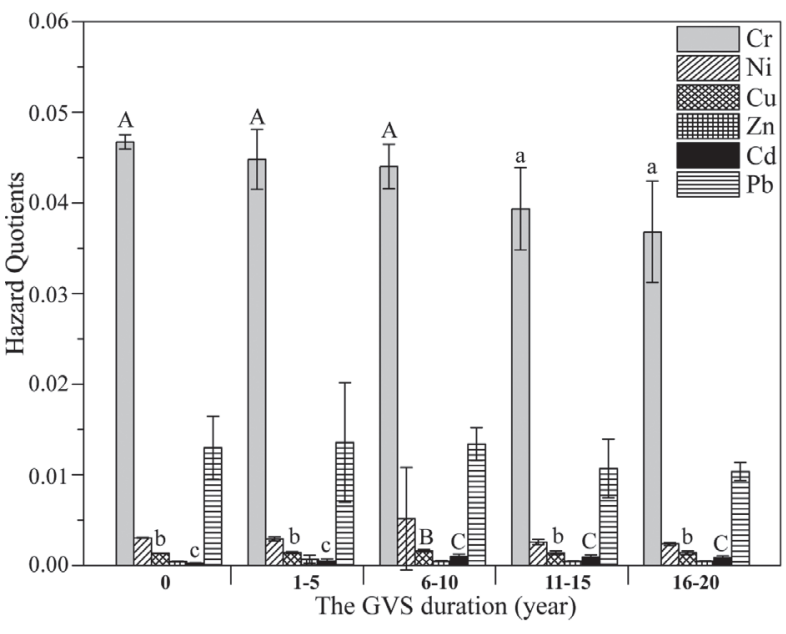

Fig. 6. Hazard quotients of the six metals in different GVS durations; bars sharing the same capital letter or the same lowercase letter are not significant at $\alpha=0.05$ (Duncan test).

The $\mathrm{CDI}_{\text {ingestion }}$ of $\mathrm{Cr}$ and $\mathrm{Cd}$ were 0.13 and $0.16 \mathrm{ug} \cdot \mathrm{day}^{-1}$ respectively. With a mean value of 0.04 , $\mathrm{Cr}$ had the highest HQ in this study, followed by HQ of $\mathrm{Pb}$ (0.012). HQ of $\mathrm{Cr}$ was significantly higher in GVS duration of the first decade (0.045) than that of the second decade duration (0.038), leading to the same trend in the HI (Fig. 6). The HQ was far less than one, which indicated a low health risk. Moreover, the carcinogenic risk of $\mathrm{Cd}$ also showed significantly lower than the threshold value $\left(1 \times 10^{-6} \sim 1 \times 10^{-4}\right)$, suggesting little carcinogenic risk.

\section{Discussion}

\section{Concentration and Distribution of Heavy Metals}

The decreased trend of $\mathrm{Cr}$ with the increase in GVS duration in this study was not consistent with the trend in the reports of Fang et al. (2011), who revealed the increasing accumulation of $\mathrm{Cr}$ as cultivation time increased [29]. Previous reports showed that $\mathrm{Cr}$ had no significant difference between GVS and open fields, and the concentration of $\mathrm{Cr}$ in vegetables was higher than other metals $[30,31]$. Thus, the decreased $\mathrm{Cr}$ in this study may suggest that $\mathrm{Cr}$ is easily transferred from soils to vegetables with the increase in GVS duration, and the transfer of $\mathrm{Cr}$ may also be related with the change of soil structure [32]. Peaks are shown in the distribution of $\mathrm{Cu}, \mathrm{Zn}, \mathrm{Cd}$, and $\mathrm{Pb}$ with the increase in GVS duration, which coincide with the distribution of $\mathrm{Cu}, \mathrm{Pb}$, and $\mathrm{Zn}$ in the report of Zhang et al. [11]. Concentrations of $\mathrm{CaCl}_{2}$-extractable $\mathrm{Cd}$ and $\mathrm{Cu}$ in GVS duration of 6-10 years are the highest with the increase in GVS duration, and $\mathrm{Ni}, \mathrm{Cu}$, and $\mathrm{Cd}$ reach the highest values in GVS duration of 6-10 years [8]. Thus, this finding indicates that this cultivation duration is vulnerable to the metal accumulation, and it may also be associated with the organic matter in soils [32]. Metal of $\mathrm{Pb}$ is significantly higher in the first decade duration than the second decade duration of GVS, whereas $\mathrm{Cd}$ has a reverse trend. The finding may be associated to the input of fertilizer and their existing forms, as both extractable fractions of $\mathrm{Cd}$ and residual fraction of $\mathrm{Pb}$ dominate the soils $[33,34]$.

Previous reports showed that contents of $\mathrm{Ni}, \mathrm{Pb}, \mathrm{Cu}$, $\mathrm{Cd}, \mathrm{Cr}$, and $\mathrm{Zn}$ had a decreased trend with the sampling depths in sediments of the Pearl River estuary [12, 33]. Whereas Li et al. (2009) showed the heavy metals in soils of 0-20 cm and 20-40 cm followed the exponential regression equations and the linear equations respectively in a historical sewage farm during 105 years, revealing that the distribution pattern of heavy metals in soil profile is related with historical land use [35]. The trend of intensive metal accumulation in soil depths of 20-40 cm may be related to the soil plowing and turning up, whereas the relative low concentrations of the metals in surface soils may be associated with metal activation and plant bio-accumulation, which can be further confirmed by the significantly low $\mathrm{pH}$ and surface soil acidification. For example, Schneider et al. (2017) showed that metal contamination in soil profile was related to the soil digging and ploughing, which can increase soil quality and crop yield [36]. The significantly lower $\mathrm{pH}$ in top-soils than deep-soils may increase the available contents of certain metals in surface soils [37].

\section{Source Identification}

The higher concentrations of $\mathrm{Cr}, \mathrm{Ni}, \mathrm{Cu}, \mathrm{Zn}$, $\mathrm{Cd}$, and $\mathrm{Pb}$ in GVS than the background values indicate anthropogenic effects [38], a finding that is in accordance with the significantly high $\mathrm{CV}$ of $\mathrm{Zn}, \mathrm{Cd}$, and $\mathrm{Pb}$ - especially in the first lustrum duration of GVS, which demonstrate that GVS is prone to metal accumulation and can be affected by farming activities in this cultivation stage. Factor analysis, principle component analysis and cluster analysis were also used to explore the sources of heavy metals in soils and sediments in previous studies [12, 39, 40]. The cluster of $\mathrm{Cr}, \mathrm{Cu}$, and $\mathrm{Ni}$ indicated their similar human inputs, and so was the cluster of $\mathrm{Pb}$ and $\mathrm{Zn}$. Qiutong and Mingkui (2017) reported that the contamination of $\mathrm{Cd}$ mainly resulted from the amendment of chemical fertilizer, and the contamination of $\mathrm{Cu}, \mathrm{Zn}$ and $\mathrm{Pb}$ were most from the input of organic manure [21, 31, 34]. Therefore, the $\mathrm{Pb}$ and $\mathrm{Zn}$ are mainly from the application of organic manure in this study. Longterm use of pesticides and chemical fertilizers could highly elevate the concentrations of $\mathrm{Cd}$ [41], and many common pesticides had significantly higher concentrations of $\mathrm{Cd}$ [42]. Thus, the significantly higher $\mathrm{Cd}$ in this study than in GVS of other provinces may suggest the excessive input of chemical fertilizer and pesticides. 


\section{Risk Evaluation}

The potential ecological risk assessment indicated the risk index of the six metals to the ecological environment, as well as the metal contamination levels [12]. Metals of $\mathrm{Cr}$ and $\mathrm{Cu}$ are at low ecological risk, though they have significant differences among the GVS duration. The significantly higher $\mathrm{Cd}$ in GVS duration of six to 20 years than in duration of 1-5 years indicates the moderate ecological risk. Thus, the metal accumulation and potential risk of $\mathrm{Cd}$ should be paid great attention. Qiutong and Mingkui (2017) showed that the concentration of $\mathrm{Cd}$ was the highest in soils amended by inorganic fertilizer, followed by soil amended by organic manure and compound fertilizer; thus the components of fertilizer should be optimized [34]. Guo et al. (2018) showed that the excessive input of organic manure cannot be utilized absolutely to elevate vegetable production, so the fertilization frequency should be reasonable [43].

Health index (HI) of adults by incidental ingestion in this study indicates the health risk when people farm. $\mathrm{HQ}$ of $\mathrm{Cr}$ and $\mathrm{Pb}$ dominate the $\mathrm{HI}$ and the values in this study below the threshold, which reveal little health risk. The carcinogenic risk of $\mathrm{Cd}$ in this study is also below the threshold, suggesting little carcinogenic possibility through the ingestion of GVS.

\section{Conclusions}

This study expounded the temporal and vertical distribution pattern of $\mathrm{Cr}, \mathrm{Ni}, \mathrm{Cu}, \mathrm{Zn}, \mathrm{Cd}$, and $\mathrm{Pb}$, identified the sources, and assessed the potential ecological risk and health risk in GVS duration of the last 20 years. The results presented support the following conclusions:

(1) The six metals had various distribution characteristic in GVS of two-decade duration.

(2) Elements of $\mathrm{Cr}, \mathrm{Ni}, \mathrm{Cu}$, and $\mathrm{Pb}$ are mostly from anthropogenic activities, and the high content of $\mathrm{Cd}$ indicates excessive human activities.

(3) GVS with duration of 6-10 years is in moderate ecological risk, and GVS has little non-carcinogenic risk or carcinogenic risk in this study.

The distribution and risk assessment of heavy metals in this study provide the theoretical basis for standardizing vegetable planting systems in GVS.

\section{Acknowledgements}

This study is financially supported by The Science Foundation of Shandong Jianzhu University (grant Nos. X18047Z and XNBS1824 from Qingqing Cao and Bing Liu, respectively).

\section{Conflict of Interest}

The authors declare no conflict of interest.

\section{References}

1. ZHANG J., YU F., PANG S., YU Y. Spatial Distribution and Pollution Assessment of Potentially Toxic Elements in Urban Forest Soil of Nanjing, China. Pol. J. Environ. Stud. 28, 3015, 2019.

2. BIAN B., LIN C., LV L. Health risk assessment of heavy metals in soil-plant system amended with biogas slurry in Taihu Basin, China. Environ. Sci. Pollut. Res. Int. 23, 16955, 2016.

3. FAN Y., LI H., XUE Z., ZHANG Q., CHENG F. Accumulation characteristics and potential risk of heavy metals in soil-vegetable system under greenhouse cultivation condition in Northern China. Ecol. Eng. 102, 367, 2017.

4. CAI L., XU Z., BAO P., HE M., DOU L., CHEN L., ZHOU Y., ZHU Y. Multivariate and geostatistical analyses of the spatial distribution and source of arsenic and heavy metals in the agricultural soils in Shunde, Southeast China. J. Geochem. Explor. 148, 189, 2015.

5. JANKIEWICZ B., ADAMCZYK D. Assessing heavy metal content in soils surrounding a power plant. Pol. J. Environ. Stud. 19, 849, 2010.

6. BERGHOFER R., WILCKE W., VLADIMIR L., NESTROV O., ZECH W. Changes of Al and heavy metal concentrations in slovak soils during the last 25 years. J. Plant. Nutr. Soil. Sc. 160, 469, 2010.

7. CHEN B., YANG H., ZHOU J., REN X., MA J., SUN L., LI X. Effect of cultivating years of vegetable field on soil heavy metal content and enzyme activity in plastic shed. Trans. Chin. Soc. Agr. Eng. 28, 213, 2012.

8. YANG L., HUANG B., HU W., CHEN Y., MAO M., YAO L. The impact of greenhouse vegetable farming duration and soil types on phytoavailability of heavy metals and their health risk in Eastern China. Chemosphere, 103, 121, 2014.

9. PING L., LI Y., SHU-FANG Y.U., LIU Z.H., WEI J.L., WANG X.J. Evaluation on environmental quality of heavy metal contents in soils of vegetable greenhouses in Shouguang city. Res. Environ. Sci. 21, 66, 2008.

10. LIU J., HUANG B., SUN W.X., ZONG L.G. Spatialtemporal distribution and prediction of heavy metals under different soil use patterns in an economically developed area. Soils. 43, 210, 2011.

11. ZHANG H., HUANG B., DONG L., HU W., AKHTAR M.S., QU M. Accumulation, sources and health risks of trace metals in elevated geochemical background soils used for greenhouse vegetable production in southwestern China. Ecotox. Environ. Safe. 137, 233, 2017.

12. KONG X., CAO J., TANG R., ZHANG S., DONG F. Pollution of intensively managed greenhouse soils by nutrients and heavy metals in the yellow river irrigation region, Northwest China. Environ. Monit. Assess. 186, 7719, 2014.

13. SUN Y. Ecological risk evaluation of heavy metal pollution in soil in Yanggu. Pol. J. Environ. Stud. 26, 1, 2017.

14. LUO C., LIU C., WANG Y., LIU X., LI F., ZHANG G., LI $\mathrm{X}$. Heavy metal contamination in soils and vegetables near 
an e-waste processing site, South China. J. Hazard. Mater. 186, 481, 2011.

15. SZYMAN SKACHABOWSKA A., BECK A., POREBA R., ANDRZEJAK R., ANTONOWICZJUCHNIEWICA J. Evaluation of DNA damage in people occupationally exposed to arsenic and some heavy metals. Pol. J. Environ. Stud. 1, 2009.

16. FALLAHZADEH R.A., GHANEIAN M.T., MIRI M., DASHTI M.M. Spatial analysis and health risk assessment of heavy metals concentration in drinking water resources. Environ. Sci. Pollut. Res. 24, 1, 2017.

17. MA W., DING X., LONG J., WANG L., LIU H., LIU S., DAI J. Source analysis and risk assessment of polycyclic aromatic hydrocarbons (PAHs) in paddy soils. Soil. Sediment. Contam. 26, 1, 2017.

18. LU R. Agricultural chemical analysis method of soil. China Agricultural Science and Technology Press. 2000.

19. SONG H., SUN Z. Temporal variations and bioaccumulation of heavy metals in different suaeda salsa, marshes of the yellow river estuary, China. Environ. Sci. Pollut. Res. 21, 14174, 2014.

20. CHEN Y., HUANG B., HU W., WEINDORF D.C., LIU X., YANG L. Accumulation and ecological effects of soil heavy metals in conventional and organic greenhouse vegetable production systems in Nanjing, China. Environ. Earth. Sci. 71, 3605, 2014.

21. TIAN K., HU W., XING Z., HUANG B., JIA M., WAN M. Determination and evaluation of heavy metals in soils under two different greenhouse vegetable production systems in eastern China. Chemosphere. 165, 555, 2016.

22. SHIRI J., KESHAVARZI A., KISI O., ITURRANRANVIVEROS U., BAGHERZADEH A., MOUSAVI R., KARIMIA S. Modeling soil cation exchange capacity using soil parameters: assessing the heuristic models. Comput. Electron. Agr. 135, 242, 2017.

23. HAKANSON L. An ecological risk index for aquatic pollution control. A sedimentological approach. Water. Res. 14, 975, 1980.

24. NATIONAL BUREAU OF STATISTICS OF CHINA. China Statistical Yearbook (in Chinese). China Statistics Press, Beijing. 2015.

25. STATE ENVIRONMENTAL PROTECTION BUREAU, STATE BUREAU OF TECHNICAL SUPERVISION. National environmental soil quality standard (GB156181995). China Standard Press, Beijing. 1997.

26. ENVIRONMENTAL PROTECTION AGENCY (EPA). Final draft bat guidance note on best available techniques for the initial melting and production of iron \& steel sector. 2011.

27. HU W., CHEN Y., HUANG B., NIEDERMANN S. Health risk assessment of heavy metals in soils and vegetables from a typical greenhouse vegetable production system in China. Human. Ecol. Risk. Assess. 20, 1264, 2014.

28. USDOE N.E., SERVICES E. Technical data to justify full burnup credit in criticality safety licensing analysis. Office of Scientific \& Technical Information Technical Reports, 2011.

29. FANG S.B., HU H., SUN W.C., PAN J.J. Spatial variations of heavy metals in the soils of vegetable-growing land along urban-rural gradient of Nanjing, China. Int. J. Environ. Res. Public. Health. 8, 1805, 2011.
30. PING L., ZHAO H.J., WANG L.L., LIU Z.H., WEI J.L., WANG Y.Q., JIANG L.H., DONG L., ZHANG Y.F. Analysis of heavy metal sources for vegetable soils from Shandong Province, China. J. Integr. Agr. 10, 109, 2011.

31. XU L., LU A., WANG J., MA Z., PAN L., FENG X., LUAN Y. Accumulation status, sources and phytoavailability of metals in greenhouse vegetable production systems in Beijing, China. Ecotox. Environ. Safe. 122, 214, 2015.

32. BAREEN B., RAFIQ K., SHAFIQ M., NAZIR A. Uptake and Leaching of $\mathrm{Cu}, \mathrm{Cd}$, and $\mathrm{Cr}$ after EDTA Application in Sand Columns Using Sorghum and Pearl Millet. Pol. J. Environ. Stud. 28, 2065, 2019.

33. LIU B., WU F., DAI X., LIU F., MI B. Variations of cadmium accumulation and translocation in different pakchoi cultivars and screening for Cd-pollution-safe cultivars using cluster analysis. Pol. J. Environ. Stud. 28, $2215,2019$.

34. QIUTONG X., MINGKUI Z. Source identification and exchangeability of heavy metals accumulated in vegetable soils in the coastal plain of eastern Zhejiang Province, China. Ecotox. Environ. Safe. 142, 410. 2017.

35. LI P.J., STAGNitTI F., XIONG X., PETERSON J. Temporal and spatial distribution patterns of heavy metals in soil at a long-standing sewage farm. Environ. Monitor. Assess. 149, 275, 2009.

36. SCHNEIDER F., DON A., HENNINGS I., SCHMITTMANN O., SEIDEL S.J. The effect of deep tillage on crop yield - what do we really know? Soil. Till. Res. 174, 193, 2017.

37. SINGH R.P., AGRAWAL M. Effects of sewage sludge amendment on heavy metal accumulation and consequent responses of beta vulgaris plants. Chemosphere. 67, 2229, 2007.

38. LI Q., GAO Y. Remediation of $\mathrm{Cd}-, \mathrm{Pb}-$ and $\mathrm{Cu}-$ Contaminated Agricultural Soils by Phosphate Fertilization and Applying Biochar. Pol. J. Environ. Stud. 28, 2697, 2019.

39. CAO Q., SONG Y., ZHANG Y., WANG R., LIU J. Risk analysis on heavy metal contamination in sediments of rivers flowing into Nansi Lake. Environ. Sci. Pollut. Res. 24, 1, 2015.

40. GAN Y., MIAO Y., WANG L., LI Y., WANG W., DAI J. Source contribution analysis and collaborative assessment of heavy metals in vegetable-growing soils. J. Agric. Food. Chem. 66, 10943, 2018.

41. BAHMAN Y., SONA A. Long-term effects of pesticides and chemical fertilizers usage on some soil properties and accumulation of heavy metals in the soil (case study of Moghan plain's (Iran) irrigation and drainage network) Intl. J. Agri. Crop. Sci. 7, 518, 2014.

42. GIMENO-GARCIA E., ANDREU V., BOLUDA R. Incidence of heavy metals in the application of inorganic fertilizers to rice farming soils (Valencia, Spain). Fertilizer. Environ. 66, 491, 1996.

43. GUO T., LOU C., ZHAI W., TANG X., HASHMI M.Z., MURTAZA R., LI Y., LIU X., XU J. Increased occurrence of heavy metals, antibiotics and resistance genes in surface soil after long-term application of manure. Sci. Total. Environ. 635, 995, 2018. 
